\title{
Stoking the Internal Fire
}

I'm enormously interested in how things work, and science satisfied my curious nature best. I had the ability of not having been steered into a "good career for a girl." I was encouraged to do whatever appealed to me. My biggest mentor was my college advisor, who taught organic chemistry. He was enormously interested in making every student he was responsible for succeed, and he made chemistry a joy. His classes were fun, and he was very encouraging. I am still in touch with him.

I majored in chemistry as an undergraduate, but focused more on biochemistry at the graduate level at Boston University. By that time, I knew I wanted to go to a graduate school that also had a medical school, to be able to do human-related research. I went directly to industry to be closer to something that would get into medical practice. I've been in the diagnostics industry for about 25 years.

The only thing I've done that was not in a diagnostics company was the 4 years I spent at Celera working on the human genome and trying to understand genetic variation. It was a unique opportunity to be part of something really exciting in basic science. I then went back to diagnostics at Roche, where I've been for 18 months.

The most important thing is to find that part of science that you just love. I can remember in graduate school thinking, "How could someone work on something for 20 years and still be excited about it?" So I found the thing that I was excited about, which was molecular diagnostics. I've been working on it for 12 years now, and I'm sure I'll finish my career in it because it is still extremely exciting. My best advice is to keep rotating until you find the thing that kindles that internal fire.

A challenge as a scientist is to be able to stay current. You can't ever say, "Oh, I'm finished with school now." I subscribe to a few key journals, rely on an alert service and as-needed searches, and go to multiple scientific meetings a year. Also, every piece I need to read goes into a bag in my office, and any time I go anywhere where I might have to wait, I'm reading something.
I have a little bit of time left for hobbies. I think it's really important to have something completely not work-related. I sing in my church choir, which is more forgiving of my travel schedule than other choral groups. I exercise every day, which is good for your mental, physical, and spiritual health.

Part of my years of experience has been learning to accept that it takes a while for new things to reach medical practice. The first research paper that reports a cool new thing doesn't immediately spark the whole medical community to change what they're doing. It's sometimes as long as 10 years between that initial report and real practical implementation. I think the reality of the genome project and personalized medicine will come eventually. The first things we're seeing now are mostly in cancer, where tumors are tested and typed on a molecular basis to understand what changes them from normal tissue into cancer. People's treatments are being selected based on those specific changes.

I consider community service part of my job. We're trying to make sure the public, including people who graduated from high school and physicians who graduated from medical school years ago before anybody ever thought about this, understands how the genome project and genetics are likely to help them. My public policy work is also driven by a desire to ensure that access to treatment isn't driven by things like reimbursement.

I'm one of 13 individuals Secretary of Health and Human Services Tommy Thompson has invited to be on his Advisory Committee on Genetics, Health, and Society. Our common interest is how genetics will affect society. We advise the Secretary, who has a direct role in research funding and legislation, including the genetic privacy act. We've recommended that he generate support for legislation to prevent people from being discriminated against for healthcare and employment purposes based on their genetic makeup.

As told to Lynne Lederman, Ph.D., a medical writer based in Wellesley, MA. 